\title{
Ultrastructural Differences between Pinocytosis in Barley Root Cells Induced by Uranyl Acetate and Plasma Membrane Modification in Susceptible Leaf Cells of Japanese Pear Caused by AK-Toxin
}

\author{
Pyoyun PARK* \\ 朴 杓允*：酶酸ウラニウム処理オオムギ根細胞にお污る pinocytosis と AK-toxin \\ 処理日本ナシ葉細胞に扔ける原形質膜の変性の微細構造上の相異
}

\begin{abstract}
Uranyl acetate caused pinocytosis in cortical cells of barley roots. Uranyl crystals were seen in cell wall and vacuoles of the cells and intercellular spaces $4 \mathrm{hr}$ after exposure to $2 \mathrm{mM}$ uranyl acetate solution. Pinocytotic invaginations of plasma membrane were observed near the crystal-deposited area of cell wall, but the invaginated spaces contained no inclusive materials, in contrast to the invaginations of plasma membrane of susceptible Japanese pear caused by AK-toxin, a host-specific toxin produced by Alternaria kikuchiana. The toxin-induced invagination produced a space that contained membranous materials of plasma membrane-origin and central cores extended from plasmodesmata. The first detectable modifications of plasma membrane occur at the plasmodesmatal area within $1 \mathrm{hr}$ after treatment. The membrane modifications gradually expanded from plasmodesmatal area to other area where plasmodesmata were not seen as incubation time was prolonged. Thus the deformed plasmodesma is one of characteristic plasma membrane modifications caused by AK-toxin. These results indicated that pinocytosis is an ultrastructural change of plasma membrane with normal function whereas the invaginations of plasma membrane in the toxintreated and infected plant tissues accompany ultrastructural changes of membrane with altered function.
\end{abstract}

(Received May 6, 1977)

\section{Introduction}

A host-specific toxin (AK-toxin) produced by Alternaria kikuchiana Tanaka, the causal fungus of black spot disease of Japanese pear, induced invaginations of plasma membrane concurrent with permeability changes in susceptible pear cells $5,6,9,10)$. Similar invaginations of the membrane were observed in pear leaf cells treated with citrinin, a model compound for AK-toxin ${ }^{5,8)}$ and inoculated with spores of $A$. kikuchiana $^{7)}$ and apple and pear leaves treated with a host-specific toxin (AM-toxin I) produced by $A$. mali Roberts which is the causal fungus of Alternaria blotch disease of apple ${ }^{11)}$.

Plasma membrane in plant cells governs all permeability processes from simple diffusion to active transport. Pinocytosis represents one of the dynamic functions in plasma membrane, but is not disorganization of the membrane. One of the problems encountered in ultrastructural studies on pinocytosis was the absence of an inducer of pinocytosis. Recently, uranyl acetate was observed to induce pinocytosis

* Faculty of Agriculture, Kyoto University, Sakyo-ku, Kyoto 606, Japan 京都大学農学部 
in plants ${ }^{15 \sim 18)}$. The modifications of plasma membrane elicited by AK-toxin $\left.5,6,9,10\right)$, AM-toxin $\mathrm{I}^{11}$ and citrinin $^{8)}$ are very similar to the pinocytotic invaginations of plasma membrane induced by uranyl acetate.

The objective of this paper is to investigate the ultrastructural differences between pinocytosis in barley roots caused by uranyl acetate and plasma membrane modification elicited by AK-toxin in susceptibie pear cells in order to show that the modification involves a disorganization of plasma membrane. Another objective is to elucidate the ultrastructural changes of plasmodesmata accompanied by the membrane modification in the toxin-treated susceptible pear cells.

\section{Materials and Methods}

Preparation of AK-toxin. AK-toxin was prepared from the culture filtrate of virulent isolate of A. kikuchiana as described previously ${ }^{10)}$. Concentration of AKtoxin solution was adjusted to give an effective permeability change in susceptible pear leaves within 10 min of the treatment.

Plants and treatments. Susceptible (cultivar Nijisseiki) and resistant leaves (cultivar Chojuro) of Japanese pear (Pyrus serotina Rehd.) were cut slightly with a scalpel. Drops of the toxin solution were placed on the injured portions of the leaves. The leaves were incubated in a moist chamber for $1 \mathrm{hr}, 3 \mathrm{hr}$ and $6 \mathrm{hr}$ at $28 \mathrm{C}$. Distilled water was placed in the injured portions as a control. Seeds of barley (Hordeum vulgare, cultivar Goseshikoku) were washed with running water for 2 days and placed on wet sand for 3 days. The germinated seeds were sawn in a mixture of sand and soil and grown at $25 \mathrm{C}$ for 3 days. The barley roots were rinsed with distilled water and then exposed in $2 \mathrm{mM}$ uranyl acetate solution or deionized water for $4 \mathrm{hr}$.

Fixation, dehydration and embedding. The portions near the toxin-treated and untreated pear leaves were trimmed with a razor blade. The tissues were prefixed with $3 \%$ glutaraldehyde $(0.1 \mathrm{M}$ phosphate buffer, $\mathrm{pH} 7.2)$ for $2 \mathrm{hr}$ at $4 \mathrm{C}$ and postfixed with $1.5 \%$ osmic acid (0.1 M phosphate buffer, $\mathrm{pH} 7.2)$ for $1.5 \mathrm{hr}$ at $4 \mathrm{C}$. After the exposure to uranyl acetate, the apical $2 \mathrm{~mm}$ of barley roots was cut off with a razor blade. The root tissues were fixed with $3 \%$ glutaraldehyde $(0.1 \mathrm{M}$ cacodylate buffer, $\mathrm{pH} 7.2)$ for $2 \mathrm{hr}$ and postfixed with $1.5 \%$ osmic acid $(0.1 \mathrm{M}$ cacodylate buffer, $\mathrm{pH}$ 7.2) for $1 \mathrm{hr}$. All fixed tissues were dehydrated with ethanol and embedded with an Epon mixture. Thin sections were stained with $2 \%$ uranyl acetate for $20 \mathrm{~min}$ and poststained with lead citrate for $10 \mathrm{~min}$. Some sections prepared from blocks of susceptible pear leaves treated with AK-toxin or water for $6 \mathrm{hr}$ were stained with alkaline bismuth staining solution for $40 \mathrm{~min}$ at $37 \mathrm{C}{ }^{14)}$, followed by staining with $2 \%$ uranyl acetate for $30 \mathrm{~min}$ and with lead citrate for $10 \mathrm{~min}$.

\section{Results}

\section{Ultrastructure of pinocytosis in barley roots caused by uranyl acetate}

Cortical cells were characterized by cytoplasm filled with cellular organelles; each cell contained a large nucleus, small vacuoles, a large number of mitochondria, rough endoplasmic reticula, plastids with starch grains, lipid bodies, Golgi bodies and distorted cell wall (Fig. 1).

Four hours after exposure to $2 \mathrm{mM}$ uranyl acetate, needle-like crystals were seen in the intercellular spaces and in the cell wall matrix of cortical tissues (Fig. 1). The number and distribution of crystals varied with the root cells. Some of the 
cell wall matrix deposited a small quantity of the crystals (Fig. 1-A) whereas the crystals were not seen in the cell wall matrix of some other cells, but in a vacuoles (Fig. 1-B). Electron micrographs of (Figs. 2 and 3) show the cell wall with massive deposition of crystals. Pinocytotic invaginations of plasma membrane were observed near the crystal-deposited area of cell wall (Figs. 2 and 3). However, transport vesicles were not observed. Invaginated sites did not contain membranous materials and central cores extended from plasmodesmata (Fig. 3).

\section{Ultrastructure of plasmodesmata of pear leaf cells}

The distribution of plasmodesmata appeared random and was 15 to 21 per $\mu \mathrm{m}^{2}$ within the area of cell wall locating the plasmodesmata (Fig. 4). The plasmodesmata comprised plasma membrane-lined canals through cell wall; each canal contained a central core (Figs. 5 to 7 ). There was a $4-10 \mathrm{~nm}$ wide gap between the core and plasma membrane (Fig. 5). At the ends of plasmodesmata, the plasma membrane and cell wall were closely appressed to the cores, which seemed to preclude direct continuity between the cytoplasm of adjacent cells (Fig. 7). The diameter of plasmodesmata is usually at the range 45 to $70 \mathrm{~nm}$, and that of a central core is 15 to $20 \mathrm{~nm}$. Plasma membrane that lined the plasmodesmatal cores was about $8 \mathrm{~nm}$ in thickness. The space between cores and plasma membrane is crossed by faintly stained filaments of amorphous materials (Fig. 5). The filaments appeared to radiate between the cores and the plasma membrane. Rough endoplasmic reticula were often observed near the both ends of plasmodesmata (Fig. 7). The electron micrographs of Fig. 6 showed that central cores appeared to be continuous with endoplasmic reticula.

\section{Ultrastructure of plasma membrane modification in leaf cells of susceptible pear caused by AK-toxin}

The invagination of plasma membrane was the first detectable change in ultrastructure in AK-toxin-treated susceptible pear cells and often arose from the both ends of plasmodesmata between vascular sheath cells, becoming evident by $1 \mathrm{hr}$ of treatment (Fig. 8). As the result of invagination, plasmodesmata were deformed by extension of central cores within structures (Fig. 8). The invagination of plasma membrane further developed as the time of treatment was prolonged (Figs. 9 to 11). The occurrence of the invagination appeared to expand from the area of plasma membrane near plasmodesmata to the area where plasmodemsta were not seen (Table 2). Six hours after treatment, susceptible cells exhibited extensive plasma membrane modifications such as large invagination of plasma membrane, detachment of the membrane, vesiculation of the detached membranes and extension of central cores from plasmodesmata (Fig. 10). The extensive invaginations were usually found in association with many deformed plasmodesmata with extended central cores (Fig. 9). Extended central cores appeared to be detached from protoplasts as plasma membrane modification progressed (Fig. 9). Some of susceptible cells showed plasma membrane modification in the area where plasmodesmata were not seen (Fig. 11).

\section{Frequency of deformed plasmodesmata with plasma membrane-invagination}

The deformed plasmodesmata associated with membrane-invagination were observed with a high frequency in susceptible leaves treated with AK-toxin for $3 \mathrm{hr}$ and $6 \mathrm{hr}$, but were not in untreated and toxin-treated resistant leaves (Table 1). The percentage of occurrence of deformed plasmodesmata was high in the order of the vascular bundle sheath cells, their adjacent mesophyll cells and the mesophyll cells remote from the bundle sheath. The percentage became higher as the incubation time was prolonged. 
Table 1. Comparative frequency of deformed plasmodesmata with invaginated plasma membrane in susceptible and resistant leaves of Japanese pear treated with AK-toxin

\begin{tabular}{|c|c|c|c|c|c|c|c|c|c|c|c|}
\hline \multirow{3}{*}{ Cultivar } & \multirow{3}{*}{$\begin{array}{l}\text { Treat- } \\
\text { ment }\end{array}$} & \multirow{3}{*}{$\begin{array}{l}\text { Treat- } \\
\text { ment } \\
\text { time } \\
(\mathrm{hr})\end{array}$} & \multicolumn{9}{|c|}{ Deformed $\mathrm{PD}^{*}$ with invaginated plasma membrane $(\%)$} \\
\hline & & & \multicolumn{3}{|c|}{$\begin{array}{l}\text { Vascular bundle } \\
\text { sheath cell }\end{array}$} & \multicolumn{3}{|c|}{$\begin{array}{l}\text { Mesophyll cell adjacent } \\
\text { to bundle sheath }\end{array}$} & \multicolumn{3}{|c|}{$\begin{array}{l}\text { Mesophyll cell remote } \\
\text { from bundle sheath }\end{array}$} \\
\hline & & & $\begin{array}{l}\text { No. of } \\
\text { observed } \\
\text { PD }\end{array}$ & $\begin{array}{l}\text { No. of } \mathrm{PD} \\
\text { with in } \\
\text { vagination }\end{array}$ & & $\begin{array}{l}\text { No. of } \\
\text { observed } \\
\text { PD }\end{array}$ & $\begin{array}{l}\text { No. of PD } \\
\text { with in- } \\
\text { vagination }\end{array}$ & & $\begin{array}{l}\text { No. of } \\
\text { observed } \\
\text { PD }\end{array}$ & $\begin{array}{l}\text { No. of PD } \\
\text { with in-- } \\
\text { vagination }\end{array}$ & \\
\hline Vijisseiki & Water & 3 & 118 & 0 & 0 & 92 & 0 & 0 & 98 & 0 & \\
\hline Nijisseiki & Toxin & 3 & 151 & 118 & 78 & 101 & 57 & 56 & 87 & 26 & \\
\hline Chojuro & Water & 3 & 123 & 0 & 0 & 95 & 0 & 0 & 102 & 0 & \\
\hline Chojuro & Toxin & 3 & 134 & 0 & 0 & 109 & 0 & 0 & 96 & 0 & \\
\hline Nijisseiki & Water & 6 & 88 & 0 & 0 & 95 & 0 & 0 & 87 & 0 & \\
\hline Nijisseiki & Toxin & 6 & 202 & 197 & 98 & 291 & 230 & 79 & 147 & 79 & \\
\hline Chojuro & Water & 6 & 150 & 0 & 0 & 104 & 0 & 0 & 111 & 0 & \\
\hline Chojuro & Toxin & 6 & 194 & 0 & 0 & 133 & 0 & 0 & 121 & 0 & \\
\hline
\end{tabular}

* PD indicates plasmodesmata.

\section{Frequency of plasma membrane-invagination at plasmodesmata}

The shorter was the time of treatment, the higher was the percentage of plasma membrane-invagination at plasmodesmata in vascular bundle sheath and their adjacent mesophyll cells of susceptible pear leaves (Table 2). The percentage was $62 \%$ in vascular bundle sheath cells treated with AK-toxin for $1 \mathrm{hr}$ whereas it decreased to $49 \%$ in those treated with the toxin for $6 \mathrm{hr}$. Similar tendency was observed in the mesophyll cells adjacent to the bundle sheath. The percentage in the mesophyll cells remote from the bundle sheath appeared to increase as incubation time was prolonged but the number of invaginations was too few to conduct a conclusion.

Table 2. Comparative frequency of plasma membrane-invagination at plasmodesmata in susceptible leaves of Japanese pear treated with AK-toxin.

\begin{tabular}{|c|c|c|c|c|c|c|c|c|c|}
\hline \multirow{3}{*}{$\begin{array}{l}\text { Treatment } \\
\text { time }(h r)\end{array}$} & \multicolumn{9}{|c|}{ Plasma membrane-invagination at $\mathrm{PD}^{*}(\%)$} \\
\hline & \multicolumn{3}{|c|}{$\begin{array}{l}\text { Vascular bundle sheath } \\
\text { cell }\end{array}$} & \multicolumn{3}{|c|}{$\begin{array}{l}\text { Mesophyll cell adjacent } \\
\text { to bundle sheath }\end{array}$} & \multicolumn{3}{|c|}{$\begin{array}{l}\text { Mesophyll cell remote } \\
\text { from bundle sheath }\end{array}$} \\
\hline & $\begin{array}{l}\text { No. of } \\
\text { observed } \\
\text { invagi- } \\
\text { nation }\end{array}$ & $\begin{array}{l}\text { No of in- } \\
\text { vagination } \\
\text { at PD }\end{array}$ & $\%$ & $\begin{array}{l}\text { No. of } \\
\text { observed } \\
\text { invagi- } \\
\text { nation }\end{array}$ & $\begin{array}{l}\text { No. of in- } \\
\text { vagination } \\
\text { at PD }\end{array}$ & $\%$ & $\begin{array}{l}\text { No. of } \\
\text { observed } \\
\text { invagi- } \\
\text { nation }\end{array}$ & $\begin{array}{l}\text { No. of in- } \\
\text { vagination } \\
\text { at PD }\end{array}$ & $\%$ \\
\hline 1 & 87 & 54 & 62 & 11 & 6 & 55 & 3 & 0 & 0 \\
\hline 3 & 126 & 74 & 59 & 92 & 37 & 40 & 43 & 7 & 16 \\
\hline 6 & 100 & 49 & 49 & 105 & 39 & 37 & 87 & 34 & 39 \\
\hline
\end{tabular}

* PD indicates plasmodesmata.

\section{Discussion}

As uranyl-treated barley roots were fixed with fixatives buffered with cacodylate buffer, the crystals seen in the roots would hardly be depositions of uranyl phosphate. However, it is most likely that the crystals are some types of uranium complex as Wheeler and Hanchey ${ }^{18}$ ) concluded previously.

Uranyl compounds are said to bind the surface of plasma membrane without entering the plant cells ${ }^{13}$. Since uranyl acetate is known to disrupt the permeability in plant cells ${ }^{2,12}$ and block uptake of various substances in plant roots ${ }^{4}$, 
the uranyl salt appears to exert some types of influences on the function and structure of plasma membrane. However, the effect of uranyl acetate on plasma membrane was apparently different from that of AK-toxin because uranyl acetate alone did not cause a rapid loss of electrolytes from plant tissues ${ }^{3)}$.

This study clearly elucidated the ultrastructural differences between pinocytotic invaginations due to uranyl acetate and plasma membrane modifications due to AKtoxin. In contrast with the absence of membranous inclusions in uranyl-induced pinocytosis, well-developed plasma membrane modifications induced by AK-toxin were accompanied by large invaginations with lomasome-like vesicles, the membranous fragments detached from plasma membrane and central cores extended from plasmodesmata. The detached membranous inclusions are features of disrupted plasma membrane as described previously ${ }^{9)}$. Another characteristic difference was found in the position of occurrence of the invagination. Pinocytotic invaginations in uranyl acetate-treated barley roots occurred near the crystal-deposited area of cell wall whereas the plasma membrane modification in AK-toxin susceptible pear leaves appeared to be restricted near the plasmodesmata (Table 1). These ultrastructural differences appear to reflect the functional differences of these invaginated plasma membranes. The pinocytotic invagination is apparently an ultrastructural change of plasma membrane retained with a normal function. However, plasma membrane modifications were accompanied by a disorganization of the membrane as observed in infected and toxin-treated plant cells, and were likely associated with permeability change.

It is observed that the invagination of plasma membrane occurred at first and most frequently at plasmodesmata (Fig. 8, Tables 1 and 2). This appears to be caused by the following reasons. The earlier contact of the toxin molecules to plasma membrane near plasmodesmata may lead to the earlier occurrence of the invagination of plasma membrane because the function of plasmodesmata is the transport of cellular materials between leaf cells ${ }^{1)}$. Besides, many and extensive invaginations may naturally contain some plasmodesmata, taking the number and distribution of plasmodesmata in leaf tissues into account (Fig. 4). The fact that the invagination was always observed to occur at the both ends of plasmodesma seems to support this interpretation (Fig. 9). The malformation of plasmodesmata appeared to be a consequence of invagination of plasma membrane and is apparently one of characteristic plasma membrane modifications caused by AK-toxin.

The writer wishes to thank Professor Masaki Yamamoto of Kyoto University for useful suggestions and review of the manuscript. The writer is also indebted to Drs. Masao Fukutomi, Jiko Shishiyama, and Iwao Furusawa of Kyoto University, Dr. Shigeyuki Mayama of Kagawa University, Professor Syoyo Nishimura of Tottori University and Dr. Seiji Ouchi of Okayama University for valuable suggestions and comments.

\section{Literature cited}

1. Arisz, W. H. (1969). Acta. Bot. Neer. $18: 14-38$.

2. Barron, E. S. G., Muntz, J. A. \& Gasvoda, B. (1948). J. Gen. Physiol. 32 : 163-178.

3. Hanchey, P. (1969). Phytopathology $59: 1960-1962$.

4. Mason, B. J., Moore, D. P. \& Maas, E. V. (1966). Nature $209: 318-319$.

5. Park, P. (1976). In Biochemistry and Cytology of Plant-Parasite Interaction (Tomiyama, K. et al. eds.) Kodansha Ltd. Tokyo pp 66-69.

6. Park, P. (1977). Ann. Phytopath. Soc. Japan $43: 15-25$.

7. Park, P. (1977). Ibid. $43: 26-32$.

8. Park, P. (1977). Ibid. $43: 183-191$. 
9. Park, P. (1977). Physiol. Plant Pathol. $11: 39-42$.

10. Park, P., Fukutomi, M., Akai, S. \& Nishimura, S. (1976). Ibid. $9: 167-174$.

11. Park, P., Tsuda, M., Hayashi, Y. \& Ueno, T. (1977). Can. J. Bot. $55: 2383-2393$.

12. Rothstein, A. (1965). In The Fungi: An Advanced Treatise, Vol 1, (Ainsworth, G. C. \& Sussman, A. S. eds.) Academic Press, pp 429-455.

13. Rothstein, A., Meier, A. \& Larabee, E. (1951). J. Cell Com. Physiol. 38: 245-270.

14. Shinji, Y., Mizuhira, V. \& Nishiyama, M. (1971). Acta. Histochem. Cytochem. 4: 248-249.

15. Wheeler, H. (1974). Can. J. Bot. $52: 1005-1009$.

16. Wheeler, H. \& Baker, B. L. (1973). J. Ultrastr. Res. 43 : 355-361.

17. Wheeler, H., Baker, B. L. \& Hanchey, P. (1972). Amer. J. Bot. 59 : 858-868.

18. Wheeler, H. \& Hanchey, P. (1971). Science $171: 68-71$.

\section{和 文 摘 要}

酢酸ウラニウム処理オオムギ根細胞における pinocytosis と AK-toxin 処理日本ナシ葉細胞に㧍ける原形質膜の变性の微細構造上の相異

$$
\text { 朴构允 }
$$

酩酸ウラニウムはオオムギ根の皮層細胞に pinocytosis をひき起しした。 $2 \mathrm{mM}$ の酶酸ウラニウムで 4 時 間処理すると，皮層細胞の細胞壁，液胞さらには細胞間隙にウラニウム結晶が観察された。pinocytosisに よる原形質膜の陥入は， 細胞壁のウラニウム結晶の 沈澱部位に 観察された。しかし，ナシ 黒斑病菌毒素 （AK-toxin）によりひき起とされる木病感受性ナシ細胞の原形質膜の陥入部にみられる封入物質は認好引れ なかった。AK-toxin により誘導された陥入は，原形質膜起源の膜物質と plasmodesmata から突出した central core を含む空間を示す。最初に見い出される原形質膜の変性は，処理 1 時間以内に plamodesmata 部位で生じる。乙の変性は，処理時間が経過するにつれて plasmodesmata 部位からこの構造が見られない 部位に搪大した。陷入により変形した plasmodesma は，AK-toxin によりひき起とされる特色ある原形質 膜変性の 1 つである。これらの結果は，pinocytosis が正常な機能をもつ原形質膜の微細構造変化であるの に反して, 毒素処理あるいは病原菌に感染した植物組織における原形質膜の陥入は, 变性した機能をもつ膜 の微細構造変化を伴なっているととを示した。

\section{Abbreviation}

c : chloroplast; cr:uranyl crystal; d : central core of a plasmodesma; er : rough endoplasmic reticulum; $f$ :filament; iv: invagination of plasma mebrane; $1 \mathrm{~b}:$ lipid body; $11 \mathrm{v}$ : lomasome-like vesicle; $m$ :mitochondrion; $\mathrm{mf}:$ membranous fragment; $\mathrm{n}:$ nucleus; $\mathrm{p}$ :plasma membrane; $\mathrm{pd}$ : plasmodesma; pt: plastid; $v$ : vacuole; $\mathrm{w}$ : cell wall.

\section{Explanation of plates}

Fig. 1-3. Ultrastructure of barley root exposed to $2 \mathrm{mM}$ uranyl acetate for $4 \mathrm{hr}$.

1) Ultrastructure of cortical cells. Uranyl crystals were first seen at the intercellular spaces. A cell (A) had crystal-deposited cell wall whereas a cell (B) had a crystaldeposited vacuole.

2) A cortical cell showing cell wall with massive deposition of crystals.

3) Pinocytotic invaginations at the crystal-deposited cell wall. Note the absence of inclusive materials in the invaginated sites.

Fig. 4-7. Ultrastructure of plasmodesmata in cells of untreated pear leaves.

4) A glancing section of the cell wall between mesophyll cells. 
5) A transverse section of a plasmodesma. The plasmodesmatal pore was lined by plasma membrane and had a central core of $20 \mathrm{~nm}$ in diameter. Note the space between the central core and plasma membrane and the presence of filaments between the central core and plasma membrane. The black bar represents $50 \mathrm{~nm}$.

6) A longitudinal section of plasmodesmata. Rough endoplasmic reticula appeared to be continuous with a central core (arrow).

7) A longitudinal section of plasmodesmata. A plasmodesma comprises a central core and a plasmodesmatal canal was lined by plasma membrane. Rough endoplasmic reticula were observed near the both ends of plasmodesmata.

Fig. 8. Plasmodesmata between vascular bundle sheath cells of susceptible pear leaves treated with AK-toxin for $1 \mathrm{hr}$. Note the extension of central cores from plasmodesmata accompanied by the invagination of plasma membrane. The sections of Fig. 8 and 9 were triple-stained with alkaline bismuth staining solution, uranyl acetate and lead citrate.

Fig. 9-11. Ultrastructure of cells of susceptible pear leaves treated with AK-toxin for $6 \mathrm{~h}$.

9) Well-developed invaginations of plasma membrane having many malformed plasmodesmata. Extended central cores appeared to detach from protoplasts.

10) Typical plasma membrane modification with membranous materials and central cores extended from plasmodesmata.

11) Plasma membrane modification at the area where plasmodesmata were not seen. 

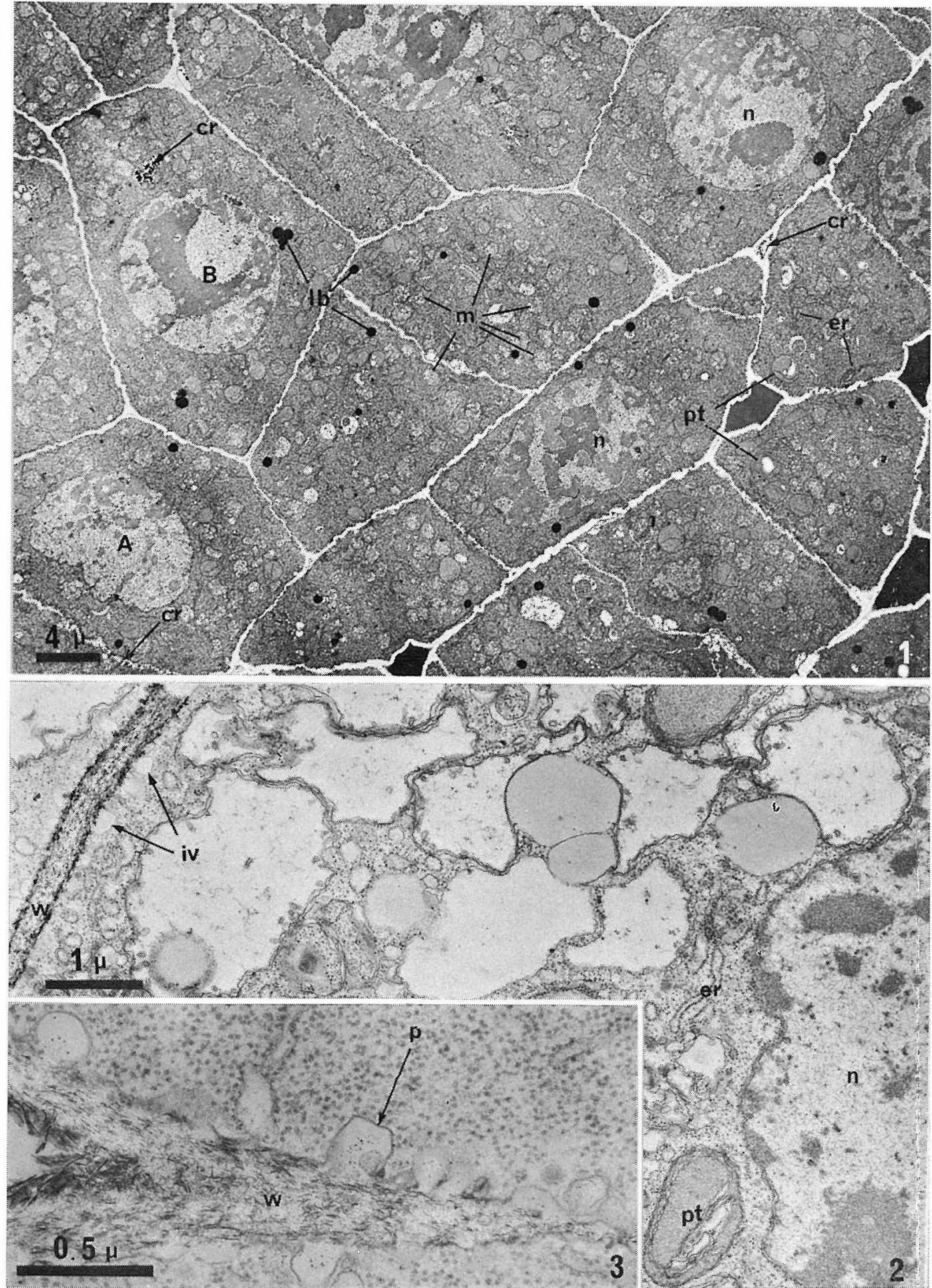


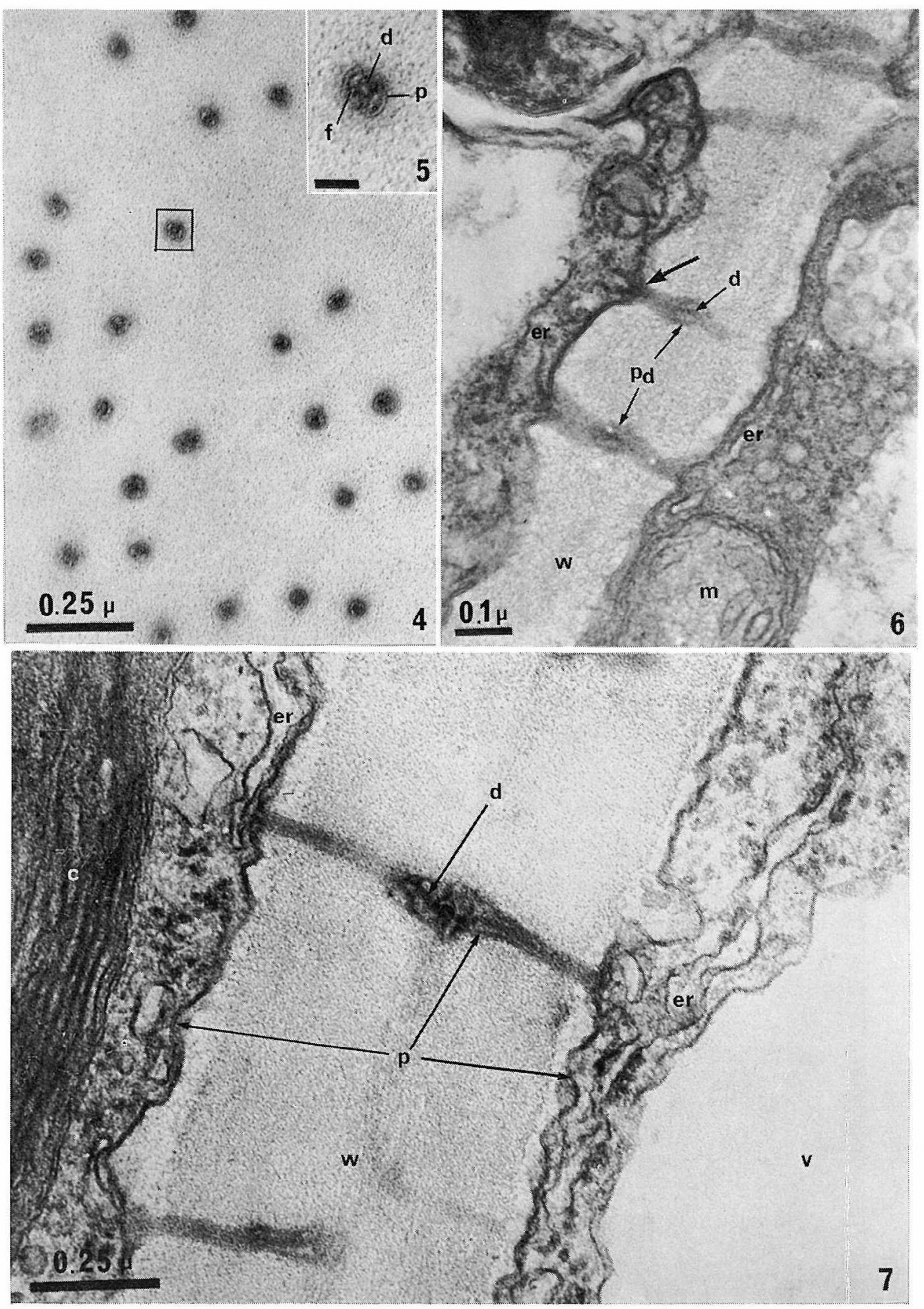



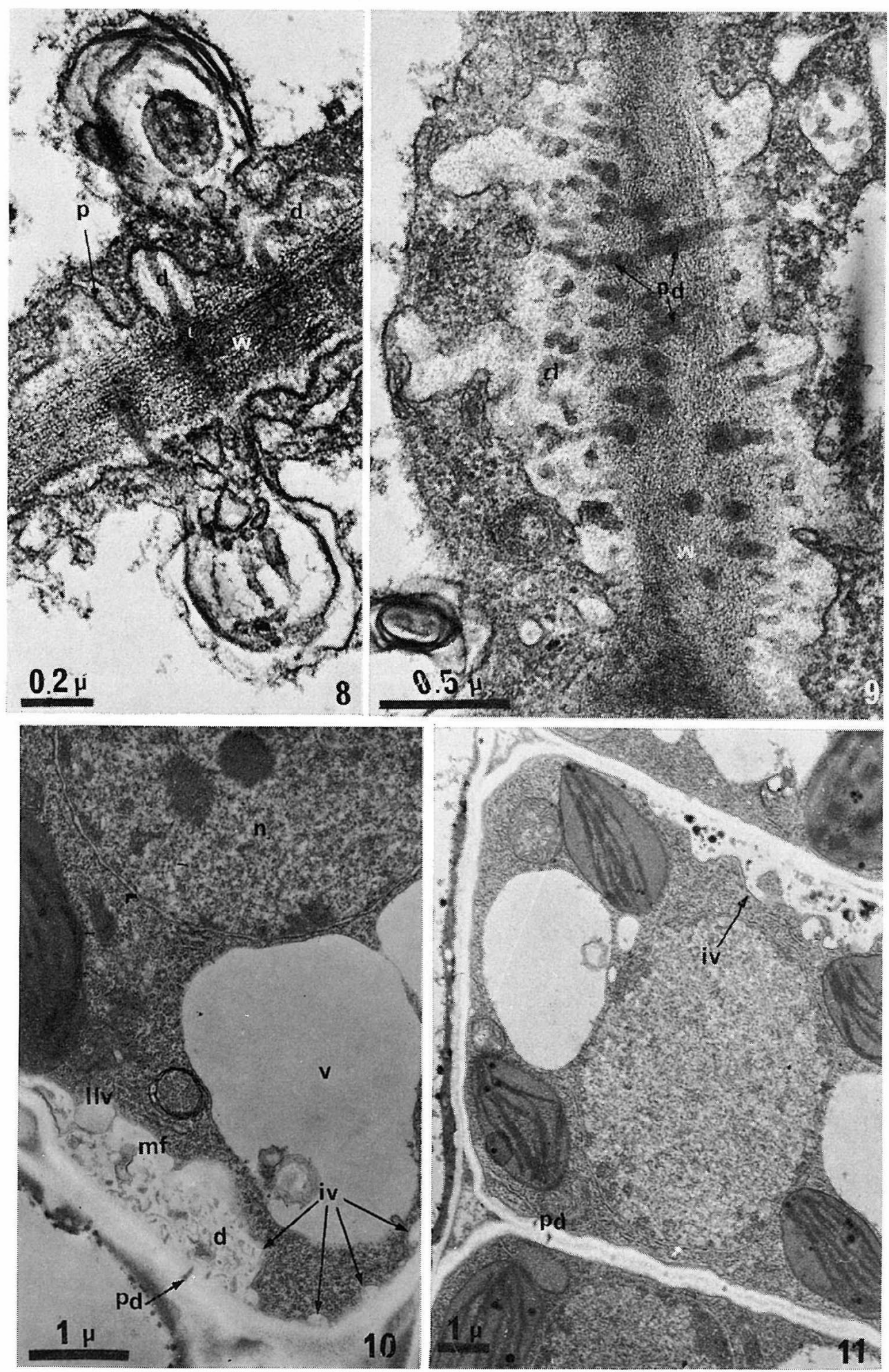